\title{
Література:
}

1. Вейзе А.А., Коношева А.В. Практическое пособие по обучению реферативному переводу. Минск: МГЛУ, 1997.

2. Камынина Т.П., Моисеева Е.В. Информационная культура как основа профессиональной компентенции будущего специалиста. Проблемы лингвистики, методики обучения иностранным язиком и литературоведению в свете международной коммуникации. Материалы III международно научной практической конференции 24-25 марта 2011 г. Уфа: Изд-во БГПУ, 2011. 324с.

3. Общеевропейские компетенции владения иностранным языком: изучение, преподавание, оценка. Совет Европы. Департамент современных языков, Страсбург. Московский государственный лингвистический университет, 2003 г. - 256 с.

DOI https://doi.org/10.30525/978-9934-26-110-7-79

\section{ОРГАНІЗАЦІЯ ГРУПОВОЇ НАВЧАЛЬНОЇ ДІЯЛЬНОСТІ СТУДЕНТІВ ПІД ЧАС ДИСТАНЦІЙНОГО ВИВЧЕННЯ СУЧАСНОЇ УКРАЇНСЬКОЇ ЛІТЕРАТУРНОЇ МОВИ}

\author{
Климович С. М. \\ кандидатка філологічних наук, \\ доцентка кафедри украӥнської філології та журналістики \\ Херсонський державний університет \\ Мартос C. A. \\ кандидатка філологічних наук, \\ доцентка кафедри украӥнської філології та журналістики \\ Херсонський державний університет \\ м. Херсон, Украӥна
}

Цілісна система навчальної діяльності здобувачів вищої освіти - це поєднання фронтальної, групової та індивідуальної діяльності. Вони вирізняються кількістю студентів та способом організації їх діяльності. Групова навчальна діяльність гармонійно поєднує індивідуальну й соціальну орієнтації в розвитку професійних здібностей здобувачів вищої освіти. Групова форма роботи студентів-філологів виконує такі основні завдання: конкретно-пізнавальне, яке пов'язане безпосередньо 3 
навчальною ситуацією; комунікативно-розвивальне, у процесі якого формуються навички спілкування у групі та за ії межами; соціальноорієнтоване, яке виховує громадянські якості, необхідні для адекватної соціалізації індивіда в суспільстві [1, с. 24].

Недостатність спілкування $\epsilon$ однією 3 проблем дистанційного навчання. Організація групової діяльності студентів усуває цей недолік, оскільки спільна діяльність реалізує прагнення до комунікації, взаємодопомоги і співпраці, зумовлює активне спілкування здобувачів вищої освіти і знижує рівень психологічної напруги, яка виникає в дистанційному навчанні. Оскільки «людина - соціальна істота, то така взаємодія покращує емоційний стан, полегшує сприйняття ізольованого навчання» $[2$, с. 154]. Застосування групових форм комунікації в системі дистанційного навчання сприятливо позначається на психолого-педагогічному аспекті освітнього процесу, «сприяє розвитку індивідуального потенціалу і студентів, і викладачів, формує мотивацію, самостійне мислення, ініціативність та відповідальність за виконувану роботу, а також знижує морально-психологічні навантаження на учасників групових форм навчання у процесі взаємного обміну знаннями» [3].

Перехід освітнього процесу в 2020-2021 роках на дистанційну і змішану форми навчання вимагав підвищення рівня цифрової грамотності педагогічних працівників. Різноманітні аспекти дистанційного навчання та використання IКТ висвітлено в наукових публікаціях фахових видань, у тезах доповідей конференцій, у електронних збірниках наукових і науково-методичних праць тощо. Організація діяльності студентів у мінігрупах під час дистанційного навчання недостатньо описана й потребує вивчення, що зумовлює актуальність нашої розвідки.

Мета публікації - презентування власного досвіду організації групової навчальної діяльності здобувачів вищої освіти під час дистанційного вивчення курсу «Сучасна українська літературна мова».

Зручний у використанні сервіс для дистанційного навчання, онлайнзустрічей і конференцій - платформа Zoom - у Херсонському державному університеті рекомендований для онлайн-навчання. Ідентифікатори й паролі конференцій (лекційних і практичних занять, консультацій, форм підсумкового контролю тощо) зазначені в розкладі занять студентів. Використання сервісу Zoom у дистанційному навчанні має низку переваг: можливість під час заняття демонструвати матеріал на робочому столі; використовувати інтерактивну дошку; планувати час занять i заздалегідь запрошувати студентів; здійснювати запис конференції; передавати повідомлення і матеріали через чат тощо. 
Для організації групової навчальної діяльності здобувачів вищої освіти на платформі Zoom зручною й ефективною є функція «сесійні зали», яка дозволяє поділити конференцію на окремі секції для обговорення. Викладач може створити окремі сесійні зали вручну або автоматично. Загальна технологія використання сесійних залів передбачає попередню підготовку (інструктаж) до виконання завдань у мінігрупах, формування груп, колективне обговорення й виконання завдань, презентування результатів діяльності кожної з груп.

Під час дистанційного вивчення дисципліни «Сучасна українська літературна мова» неодноразово використовували сесійні зали для налагодження роботи студентів у мінігрупах. Наприклад, опрацьовуючи тему «Правопис слів разом, з дефісом та окремо» (розділ «Орфографія») студенти в 4-5 сесійних залах моделювали слова 3 першим іншомовним складником бліч-, веб-, віще-, максі-, прес-, смарт-, топ-, пояснювали написання відповідно до нової редакції Українського правопису (2019). Доречним $є$ застосування сесійних залів для закріплення варіантного написання, наприклад, при вивченні питання «Особливості відмінювання іменників II відміни» (розділ «Морфологія») студенти отримали завдання 3'ясувати, чи змінюється закінчення іменників апарат, блок, звук, камінь, листопад, потяг, соняшник, термін у родовому відмінку однини при зміні значення (конкретні й абстрактні іменники, слова із значенням сукупності). Активно використовуємо сесійні зали для опрацювання синтаксису як простого, так і складного речення. Продуктивною $є$ робота в мінігрупах над творчими завдання, виконання яких мотивує студентів не лише застосувати теоретичні знання, але й скласти речення (текст) відповідно до умов завдання. Наприклад, можна запропонувати кожній групі ввести слово зрозуміти в самостійно складене речення так, щоб в одному випадку воно виступало підметом, в іншому - присудком, або виконувало функцію поширювача (означення, додатка, обставини).

Важливо, що викладач як організатор конференції може вільно переключатися між сесійними залами, спостерігаючи процес обговорення, надавати консультації, за потреби координувати діяльність мінігрупи, відповідати на запитання.

Онлайн дошка Google Jamboard $\epsilon$ ефективним засобом організації групової навчальної діяльності здобувачів вищої освіти під час дистанційного навчання. Google Jamboard має низку переваг: безкоштовність; функціонал доволі зручний та простий у користуванні; зрозумілий інтерфейс; здатність працювати з технологією як в синхронному, так і в асинхронному режимі; відсутність потреби у спеціальних навичках роботи з IКТ; записи можна зберегти для наступного використання; 
дозволяє створити максимум 20 фреймів (сторінок) на одній дошці; не має обмежень кількості учасників, які можуть на ній виконувати записи одночасно.

На практичних заняттях із сучасної української літературної мови організовували групову діяльність студентів із використанням онлайндошки Google Jamboard. Поділивши здобувачів вищої освіти на мінігрупи, пропонували спільне виконання завдань для кожної групи на окремому фреймі дошки.

Ефективним прийомом використання групової форми роботи $\epsilon$ розробка навчально-методичних матеріалів самими студентами, оскільки здатність доцільно використовувати й створювати сучасне навчальнометодичне забезпечення (обладнання) для проведення занять - одна із фахових компетентностей майбутнього вчителя української мови. Створення групових онлайн-дошок до визначених тем курсу «Сучасна українська літературна мова» формувало у майбутніх учителів потребу в творчому підході до навчання, включало елементи проєктної та дослідної роботи.

Розробка інтерактивного дидактичного матеріалу студентами сприяє грунтовному вивченню дисципліни та формуванню навчальних навичок: вони вчаться виокремлювати головне від другорядного, структурувати навчальний матеріал, добирати приклади, вправи, ілюстрації тощо. Групова навчальна діяльність здобувачів вищої освіти із використанням Google Jamboard формує навички працювати з теоретичними та науковометодичними джерелами (зокрема цифровими), знаходити, обробляти, систематизувати й застосовувати в професійній діяльності сучасну наукову інформацію, бібліографію, комп'ютерні технології.

Спільна робота студентів у мінігрупах дає можливість усім висловити власну думку, атмосфера пошуку і співпраці розвиває творчий потенціал, формує потребу в креативному підході до навчання, бажання до подальшого розвитку професійної майстерності. Оскільки здобувачів вищої освіти готують до ефективної роботи в майбутньому, в якому сьогодні велику роль мають уміння й навички співпрацювати й колективно вирішувати поставлені завдання, то групова форма організації навчання, в основі якої принцип взаємодії, допомагає розвивати майбутньому педагогові уміння й навички для подальшої успішної реалізації себе у професійній сфері.

\section{Література:}

1. Варакута О. М. Технологія групової форми організації навчальної діяльності студентів на практичних заняттях $з$ географії. Регіональні 
проблеми Украӥни: географічний аналіз та пошук шляхів вирішення. Херсон, 2013. С. 22-27.

2. Стадній А. Моделі дистанційного навчання. Актуальні питання гуманітарних наук. 2020. Вип. 29. Т. 4. С. 151-156.

3. Стрельбицька С. Взаємодія викладача зі студентами під час дистанційного навчання в освітньому просторі закладу вищої освіти. Збірник наукових пращь А'ОГОГ. 2020. С. 25-31.

DOI https://doi.org/10.30525/978-9934-26-110-7-80

\title{
РОЛЬ МУЛЬТИМЕДІЙНИХ ЗАСОБІВ У ПРОЦЕСІ ВИКЛАДАННЯ УКРАЇНСЬКОЇ МОВИ ЯК ІНОЗЕМНОЇ СТУДЕНТАМ МЕДИЧНОГО ПРОФІЛЮ НАВЧАННЯ
}

\author{
Козелко I. P. \\ кандидат філологічних наук, \\ старший викладач кафедри українознавства \\ Львівський національний медичний університет \\ імені Данила Галищького \\ м. Львів, Украӥна
}

У XXI ст. освіта в Україні спрямована на підготовку спеціалістів різних галузей науки, де на рівних правах здобувають свій фах вітчизняні та іноземні студенти. Значна частка іноземних громадян прагне здобути медичну освіту саме в Україні. Їхня увага прикута до діяльності науковців-медиків, а саме до процесу обміну інформацією з світовою спільнотою, що в умовах дистанційного навчання відбувається із залученням різних технологій навчання. Як відомо, на високому науковометодичному рівні проводиться навчання студентів-медиків також i y Львівському національному медичному університеті імені Данила Галицького, де «головним принципом підготовки лікарів є безперервність і багатоступеневість медичної освіти в залежності від обраної кваліфікації» [2, с.27].

3-поміж усіх дисциплін, що їх пропонують для студіювання у цьому університеті, чільне місце займає також предмет украӥнська мова як іноземна (далі УМІ). Зауважмо, що УМІ включено до освітніх програм більшості вузів України. На сьогодні викладачами розроблено чимало підходів, методів та методик до вивчення цієї дисципліни. Зокрема, Г.Строганова послідовно виклала концептуальні підходи на шляху до 